\title{
Increasing Students Awareness of Safety Designing Workplace Base on Ergonomic Principle Using Video
}

\author{
Illuni Islamiah Binti Ibrahim ${ }^{1}$, Jumintono ${ }^{1, *}$, Imam Kanafi ${ }^{2}$, Hafnidar Hafnidar ${ }^{3}$, Bagus Haryono ${ }^{4}$, \\ Yuniar Farida ${ }^{5}$, Silvia Rosa ${ }^{6}$, Fransiska Sinta Devi Murwaningtyas ${ }^{7}$, Ayu Esteka Sari ${ }^{8}$, \\ Riyanti Isaskar ${ }^{9}$

\begin{abstract}
${ }^{1}$ Faculty of Technical and Vocational Education, Universiti Tun Hussein Onn Malaysia, 86400 Parit Raja, Johor, Malaysia ${ }^{2}$ Department of Tasawuf Psychotherapy, Institut Agama Islam Negeri Pekalongan, 51114, Indonesia

${ }^{3}$ Department of Psychology, Malikussaleh University, Aceh Utara, 24377, Indonesia

${ }^{4}$ Department of Sociology, Faculty of Social and Political Science, Sebelas Maret University, Surakarta, 57126, Indonesia ${ }^{5}$ Department of Mathematics, Universitas Islam Negeri Sunan Ampel Surabaya, 60234, Indonesia

${ }^{6}$ Department of Literature, Faculty of Humanities, Andalas University, Padang, 25163, Indonesia

${ }^{7}$ Department of Agribisnis, Sebelas Maret University, Surakarta, 57126, Indonesia

${ }^{8}$ Department of Management, STIE Sakti Alam Kerinci, Jambi, 37111, Indonesia

${ }^{9}$ Faculty of Agriculture, Brawijaya University, Surabaya, 65145, Indonesia
\end{abstract}

Received August 30, 2020; Revised October 8, 2020; Accepted November 11, 2020

\section{Cite This Paper in the following Citation Styles}

(a): [1] Illuni Islamiah Binti Ibrahim, Jumintono, Imam Kanafi, Hafnidar Hafnidar, Bagus Haryono, Yuniar Farida, Silvia Rosa, Fransiska Sinta Devi Murwaningtyas, Ayu Esteka Sari, Riyanti Isaskar , "Increasing Students Awareness of Safety Designing Workplace Base on Ergonomic Principle Using Video," Universal Journal of Educational Research, Vol. 8, No. 12, pp. 6902 - 6907, 2020. DOI: 10.13189/ujer.2020.081256.

(b): Illuni Islamiah Binti Ibrahim, Jumintono, Imam Kanafi, Hafnidar Hafnidar, Bagus Haryono, Yuniar Farida, Silvia Rosa, Fransiska Sinta Devi Murwaningtyas, Ayu Esteka Sari, Riyanti Isaskar (2020). Increasing Students Awareness of Safety Designing Workplace Base on Ergonomic Principle Using Video. Universal Journal of Educational Research, 8(12), 6902 - 6907. DOI: 10.13189/ujer.2020.081256.

Copyright@2020 by authors, all rights reserved. Authors agree that this article remains permanently open access under the terms of the Creative Commons Attribution License 4.0 International License

\begin{abstract}
The study aims to measure the level of students' understanding of ergonomics' principles with video. This research uses a descriptive quantitative method with the survey method. This research involved six students of the Faculty of Engineering and Vocational Education, especially Mechanical Engineering at Universiti Tun Hussein Onn Malaysia (UTHM). The data were obtained using a gradual questionnaire. The first stage before the respondent watched the learning video and after watching the ergonomic learning video for 15 minutes. The questionnaires were distributed randomly to students without choosing a gender. The instrument was compared before and after watching the video. The instrument was then analyzed using descriptive statistical analysis whereby the frequency and percentage are used to analyzed data. Learning video helps students to understand basic ergonomics principles easily. Input from the concept of this video is made to make fun and easy to understand by students. This study's purpose is achieved because it
\end{abstract}

measures students' knowledge about the principle of ergonomics increasing after watching a video. The results show that student knowledge increases after watching the video Basic Ergonomics Principles at Work. Video learning can help students design a better understanding of basic ergonomics principles compared to entering the classroom.

Keywords Students Awareness, Safety, Designing Workplace, Ergonomic Principle

\section{Introduction}

Technological developments have influenced classroom learning. One of the technological developments that are affecting learning is video-based learning. Video-based learning is the delivery of material using video. Interactive 
video-based learning has a good impact on increasing student knowledge [1]. Video is a tool to increase student knowledge, which is considered easy to understand by students [2]. Video learning can increase student knowledge [3]. Strengthening school education is understanding benchmarking, professional training, and increasing trust, strong character with high integrity [4].

Education becomes a process of knowledge transfer and cannot be separated from the development of new technologies. Therefore the analysis of the use of ICT in universities is not complete without interactive discussion. They combine new technologies that will come along with the progress of time [5]. Teacher skills are an essential component for improving student learning achievement (Ramadan et al., 2018). Educational value development requires an approach that allows students to experience the transfer of values [6] directly. Pre-employment teacher training plays an essential role in achieving the learning approach [7].

Teachers in teaching must follow students' development to be more readily accepted by students [8]. Teachers today make lots of exciting videos for classroom learning. A variety of videos are produced for teaching sessions at the primary, secondary, and tertiary levels. The use of videos in teaching and learning sessions is more interactive, engaging, and creative. Improvement of students' understanding through video-based learning sessions can be seen through teacher ratings and assessments and their examination results. The use of visual learning to support classroom action not only has a significant and sustained effect, but the teacher's beliefs and self-efficacy significantly influence teaching behavior in the classroom [9]. Thus the video media is an approach that is carried out by producing a video to facilitate student retention.

Ergonomics is essential knowledge for product design. Ergonomic design can produce quality products and follow human capabilities so that a comfortable workplace can affect employee efficiency and performance [10]. A comfortable workplace can affect employee efficiency and performance. Employees will be happy and not stressed when they are at work and handle their job well. Therefore, the importance of matching workers' abilities, capacities, and health with their craft, the raw materials they handle, work posture, and work environment. Each company organization must continue to develop and adapt to new demands and offers [11].

Designing the product is a challenging need required the knowledge and skills in visual design, psychology, human-factors, ergonomic research, computer science, and editorial design. There were a lot of guidelines that are available to help the designer. However, many do not fit the specific needs of an instructional environment. Ergonomic has a primary focus on considering the human element in the design, procedures, and work environment. Ergonomics is specifically related to the production process, especially time management [12]. Some ergonomic treatments include ergonomic modifications, rest, and workout exercises [13]. This phenomenon may cause many products that do not follow the ergonomics principles. As a result, the product's user will tend to injure, such as Musculoskeletal Disorder and other injuries. Thus, the product will be categorized as low quality since it does not focus on the human factor [14].

The product design nowadays does not focus on human well-being and human performance, which positively impacts workplace outcomes and productivity. Thus, organizations benefit greatly from workplace friendships [15]. The workplace remains an essential place for supporting and promoting the health and safety of the environment. Applying the ergonomics principle can prevent injuries known as Work Musculoskeletal Disorder (WMSD) (Pavlovic-Veselinovic et al., 2016). Musculoskeletal Disorder is an internal injury involving the nerves, tendons, and ligaments [16]. It is caused by vibrations, non-stop work, stress at work, and wrong posture. Therefore, ergonomic applications' primary purpose is to ensure the design is safe, free of injury, comfortable, capable of improving employee performance and the human body [8]. In other words, ergonomic applications in design can provide convenience to humans and save time [9].

The principle of ergonomics is a crucial issue and is of concern among designers before designing products [17]. Thus, this study provides students with an understanding of ergonomic principles with the help of video tutorials. This study identifies the impact of videos on the principle of ergonomics that can improve students' understanding of learning. So video-based learning can be applied in providing material.

\section{Methods}

This research uses a descriptive quantitative method with the survey method. This design was chosen because it was very appropriate in reviewing and identifying the principle ergonomics among mechanical engineering students' education. Quantitative methods are approaches to quantitative data and involve numerical measurement [18]. This research involved six students of the Faculty of Engineering and Vocational Education, especially Mechanical Engineering at Universiti Tun Hussein Onn Malaysia (UTHM). The data were obtained using a gradual questionnaire. The first stage before the respondent watched the learning video and after watching the ergonomic learning video for 15 minutes.

The questionnaires were distributed randomly to students without choosing a gender [19]. After that, they need to answer the other similar instruments from previous regarding the video they watch. The instrument was compared before and after watching the video. The pre-test refers to the result before watching the video. The post-test 
refers to the result after watching the video. The instrument was then analyzed using descriptive statistical analysis whereby the frequency and percentage are used to analyzed data [20]. Statistical software is used to interpret research data [21].

\section{Result and Discussion}

The first question is the respondents' understanding of ergonomics fundamentally.

Table 1. What is ergonomics

\begin{tabular}{cccccc}
\hline & & \multicolumn{2}{c}{ Pre Test } & \multicolumn{2}{c}{ Post Test } \\
\cline { 2 - 6 } & & Frequency & Percent & Frequency & Percent \\
\hline \multirow{3}{*}{ Valid } & True & 1 & 16.7 & 6 & 100.0 \\
\cline { 2 - 6 } & False & 5 & 83.3 & 0 & 0 \\
\cline { 2 - 6 } & Total & 6 & 100.0 & 6 & 100.0 \\
\hline
\end{tabular}

For question 1, the pre-test results show that the percentage can answer this question is $16.7 \%$. It shows that only one respondent can answer the question, and the rest cannot answer it. For the post-test, the percentage respondent can answer question 1 is $100 \%$, which means that all respondents can answer the first question after watching the video.

Question 1 shows there has an achievement of knowledge among respondents before and after watching the video. This condition is because the majority can answer the first question compared with previously. All respondents can understand the first question, and the main purpose of the learning video to understand ergonomics is achieved.

Knowledge about the understanding of ergonomics needs to be understood simply to add respondent insight. This knowledge will be useful for them to form a comfortable workplace without injury. According to [22], even every worker needs to be given a health and safety certification trainer to understand better which ergonomic analysis tools are used in the industry.

Table 2. What is 3 type of ergonomics

\begin{tabular}{cccccc}
\hline & & \multicolumn{2}{c}{ Pre Test } & \multicolumn{2}{c}{ Post Test } \\
\cline { 2 - 6 } & & Frequency & Percent & Frequency & Percent \\
\hline \multirow{3}{*}{ Valid } & True & 2 & 33.3 & 6 & 100.0 \\
\cline { 2 - 6 } & False & 4 & 66.7 & 0 & 0 \\
\cline { 2 - 6 } & Total & 6 & 100.0 & 6 & 100.0 \\
\hline
\end{tabular}

Generally, three postural loads cause imbalanced body postures. Workers in any field always underestimate the burden in a balanced state or not [23]. Then it needs to be given an understanding of body posture using video.

The second question, the pre-test results, shows the percentage value that can answer this question is 33.3\%. The percentage that cannot answer question 2 is $66.7 \%$.
That means only two respondents can answer questions, and other respondents cannot answer the right questions. For the post-test, the percentage of respondents who answered question 2 is $100 \%$, which means that all respondents can answer the first question after watching the video.

The second question results are seen that most respondents can also better understand the principle of ergonomics. The percentage shows that all respondents can answer this question where the percentage value is $100 \%$ compared to before watching the video, which was only $33.3 \%$. Because of this, the video is easy and straightforward for everyone to watch.

Table 3. What are the advantages of applying the ergonomics principle

\begin{tabular}{cccccc}
\hline & \multicolumn{2}{c}{ Pre Test } & \multicolumn{2}{c}{ Post Test } \\
\cline { 2 - 6 } & & Frequency & Percent & Frequency & Percent \\
\hline \multirow{3}{*}{ Valid } & True & 6 & 100.0 & 4 & 66.7 \\
\cline { 2 - 6 } & False & 0 & 0 & 2 & 33.3 \\
\cline { 2 - 6 } & Total & 6 & 100.0 & 6 & 100.0 \\
\hline
\end{tabular}

The third question contains the advantages of implementing ergonomic in the workplace. According to [24], there is a significant influence on ergonomics' application to employee productivity. Respondents' understanding was observed before and after watching the video about ergonomics.

For question 3, the pre-test result shows that the percentage value can answer this question is $100 \%$, which means that all respondents can answer the first question after watching the video. While after watching the video, the results show that the percentage of respondents can answer to this question is $66.7 \%$. The rate cannot answer question 3 is $33.3 \%$, which means that only two respondents can answer the question. The other respondents cannot answer the right question.

Question 6 shows that before watching the video, all respondents can answer the question. However, after watching the video, there have only four respondents can answer the question. Thus, it shows there have a misunderstanding of this part in the video. Respondents may be confusing the question, and they are not alert from the video. This video may also do not deeply explain detail about this part. So, respondents cannot get about what the video tries to show and explain.

Table 4. Scope of ergonomics

\begin{tabular}{cccccc}
\hline & \multicolumn{2}{c}{ Pre Test } & \multicolumn{2}{c}{ Post Test } \\
\cline { 2 - 6 } & & Frequency & Percent & Frequency & Percent \\
\hline \multirow{3}{*}{ Valid } & True & 2 & 33.3 & 5 & 83.3 \\
\cline { 2 - 6 } & False & 4 & 66.7 & 1 & 16.7 \\
\cline { 2 - 6 } & Total & 6 & 100.0 & 6 & 100.0 \\
\hline
\end{tabular}

In the fourth question, the pre-test shows that the percentage value that can answer this question is 33.3\%. 
The percentage that cannot answer the question is $66.7 \%$, which means that it cannot answer question 4 . Thus, there are only two respondents who can answer questions, and there are four respondents who cannot answer questions. The post-test percentage value that after watching the video can answer the question is $83.3 \%$, where five respondents can answer the question. In contrast, the percentage of questions that cannot answer questions is $16.7 \%$. Only one respondent cannot answer this question. Thus, the video can provide respondents with an understanding of the principles of ergonomics.

Table 5. What is the Work Musculoskeletal Disorder (WMSD)

\begin{tabular}{cccccc}
\hline & \multicolumn{2}{c}{ Pre Test } & \multicolumn{2}{c}{ Post Test } \\
\cline { 2 - 6 } & & Frequency & Percent & Frequency & Percent \\
\hline \multirow{3}{*}{ Valid } & True & 4 & 66.7 & 6 & 100.0 \\
\cline { 2 - 6 } & False & 2 & 33.3 & 0 & 0 \\
\cline { 2 - 6 } & Total & 6 & 100.0 & 6 & 100.0 \\
\hline
\end{tabular}

In the fifth question, the pre-test results show that the percentage value that can answer this question is $66.7 \%$, and the percentage cannot answer question 5 is $33.3 \%$. Thus, this means that only four respondents can answer questions, and other respondents cannot answer the right questions. In the post-test, the percentage of respondents answered question 5 is $100 \%$, which means that all respondents can answer the first question after watching the video.

Percentage of questions, as many as five respondents indicated that they understood and could answer about this topic. There is an increase in the number of respondents who can answer questions from four to six. Thus, this shows that this video is easy to understand and suitable for learning about basic ergonomics.

Table 6. Example of injuries based on WMSD

\begin{tabular}{cccccc}
\hline & & \multicolumn{2}{c}{ Pre Test } & \multicolumn{2}{c}{ Post Test } \\
\cline { 2 - 6 } & & Frequency & Percent & Frequency & Percent \\
\hline \multirow{3}{*}{ Valid } & True & 6 & 100.0 & 6 & 100.0 \\
\cline { 2 - 6 } & False & 0 & 0 & 0 & 0 \\
\cline { 2 - 6 } & Total & 6 & 100.0 & 6 & 100.0 \\
\hline
\end{tabular}

The sixth question discusses WSMD (Work-related Musculoskeletal Disorders), causing temporary and permanent disability [25]. Engineering workers use a lot of muscle activity and body movements with various weights, so it needs to be given understanding. The sixth question, the pre-test percentage results, shows that all respondents can answer that is $100 \%$ can answer this question. While the post-test shows the percentage value after watching the video is also $100 \%$ where all respondents can answer questions. Question 6 does not have complicated questions because respondents for both tests showed similar results. All respondents could answer questions before and after watching the video. Therefore, this video does not have any effect on this part of the respondents.

Table 7. How to control the hazard by using the ergonomic principle

\begin{tabular}{cccccc}
\hline & & \multicolumn{2}{c}{ Pre Test } & \multicolumn{2}{c}{ Post Test } \\
\cline { 2 - 6 } & & Frequency & Percent & Frequency & Percent \\
\hline \multirow{3}{*}{ Valid } & True & 3 & 50.0 & 5 & 83.3 \\
\cline { 2 - 6 } & False & 3 & 50.0 & 1 & 16.7 \\
\cline { 2 - 6 } & Total & 6 & 100.0 & 6 & 100.0
\end{tabular}

In question 7 , the pre-test shows that the percentage value that can answer this question is $50.0 \%$. The percentage that cannot answer the question is $50.0 \%$, which means that half of the respondents can answer this question. Other respondents cannot answer this question. The post-test percentage value that after watching the video can answer the question is $83.3 \%$, where five respondents can answer the question. In comparison, the percentage of unable to answer questions is $16.7 \%$. There is only one respondent unable to answer this question. The seventh question results appear that only one person can not answer the question after watching the video. However, other respondents gave the right answer. Input on the video provides positive knowledge to the respondents. At the same time, they are easy to understand and can capture points delivered from the video. Therefore, the research objective was achieved. Namely, the level of knowledge of respondents increased after watching the video.

Majorities of respondents can answer all the questions after watching the video of the basic principle of ergonomic. It is because they become more understanding after watching the video. The video can also help people enhance their knowledge about the importance of ergonomic toward human factors. As a result, they have many people who will appreciate the ergonomic principle in their lifestyles. Therefore, the video plays an essential role in making sure people understand the basic ergonomic for their health and safety life [26].

\section{Conclusion}

Learning video helps students to understand basic ergonomics principles easily. Input from the concept of this video is made to make fun and easy to understand by students. This study's purpose is achieved because it measures students' knowledge about the principle of ergonomics increasing after watching a video. The results show that student knowledge increases after watching the video Basic Ergonomics Principles at Work. Video learning can help students design a better understanding of basic ergonomics principles compared to entering the classroom. Video is an alternative way for students to gain more knowledge about basic ergonomics. Videos are easier to understand and enjoyable to watch because respondents provide positive feedback after watching videos. This video is an alternative way for students to gain more 
knowledge about basic ergonomics. This video also was easy to understand and enjoyable to watch since the respondents give positive feedback after watching the video.

\section{Acknowledgments}

The author would like to thank Research Fund E15501, Research Management Centre, UTHM for its support and funding.

\section{REFERENCES}

[1] N. M. Preradovic, T. Lauc, and I. Panev, "The Effect of Medium of Instruction on Undergraduate Student Learning Style in Video-based Learning,” Int. J. Educ. Inf. Technol., vol. 14, pp. 1-7, Apr. 2020, DOI: 10.46300/9109.2020.14.1.

[2] E. V. Habes, P. Jepma, J. L. Parlevliet, A. Bakker, and B. M. Buurman, "Video-Based Tools to Enhance Nurses' Geriatric Knowledge: A Development and Pilot Study,” Nurse Educ. Today, vol. 90, Jul. 2020, DOI: 10.1016/j.nedt.2020.104425.

[3] V. Hoogerheide, A. Renkl, L. Fiorella, F. Paas, and T. van Gog, "Enhancing Example-Based Learning: Teaching on Video Increases Arousal and Improves Problem-Solving Performance,” J. Educ. Psychol., vol. 111, no. 1, pp. 45-56, Jan. 2019, DOI: 10.1037/edu0000272.

[4] Jumintono, Suyatno, M. Zuhaery, H. Said, and M. N. A. Azman, "Vocational Education Principal of Leadership : A Case Study in East Nusa,” J. Soc. Sci. Res., no. 6, pp. 825831, 2018, DOI: https://doi.org/10.32861/jssr.spi6.825.831.

[5] H. Ç. Bal and Ç. Erkan, "Industry 4.0 and Competitiveness," Procedia Comput. Sci., vol. 158, pp. 625-631, 2019, DOI: 10.1016/j.procs.2019.09.096.

[6] M. Suyatno, M. Jumintono, D. I. Pambudi, and A. Mardati, "Design of Values Education in School For Adolescents," Adv. Soc. Sci. Educ. Humanit. Res., vol. 134, no. Icirad, pp. 10-13, 2017, doi: 10.2991/icirad-17.2017.2.

[7] N. Türk, N. Kalayc1, and H. Yamak, "New trends in higher education in the globalizing world: STEM in teacher education,” Univers. J. Educ. Res., vol. 6, no. 6, pp. 12861304, 2018, DOI: 10.13189/ujer.2018.060620.

[8] M. Pérez, V. Ayerdi, and Z. Arroyo, "Students Engagement and Learning Through the Development of Didactic Models for Mechanical Engineering,” Univers. J. Educ. Res., vol. 6, no. 10, pp. 2300-2309, 2018, DOI: 10.13189/ujer.2018.061 029.

[9] G. Chen, “A Visual Learning Analytics (VLA) Approach to Video-Based Teacher Professional Development: Impact on Teachers' Beliefs, Self-Efficacy, And Classroom Talk Practice," Comput. Educ., vol. 144, Jan. 2020, DOI: 10.1016/j.compedu.2019.103670.

[10] Z. G. dos Santos, L. Vieira, and G. Balbinotti, "Lean Manufacturing and Ergonomic Working Conditions in the Automotive Industry,” Procedia Manuf., vol. 3, pp. 59475954, 2015, DOI: 10.1016/j.promfg.2015.07.687.
[11] B. Cirjaliu and A. Draghici, "Ergonomic Issues in Lean Manufacturing,” Procedia - Soc. Behav. Sci., vol. 221, pp. 105-110, Jun. 2016, DOI: 10.1016/j.sbspro.2016.05.095.

[12] C. Dahmen and C. Constantinescu, "Methodology of Employing Exoskeleton Technology in Manufacturing by Considering Time-Related and Ergonomics Influences,” Appl. Sci., vol. 10, no. 5, Mar. 2020, DOI: 10.3390/app10051591.

[13] A. Shariat, J. A. Cleland, M. Danae, M. Kargarfard, B. Sangelaji, and S. B. M. Tamrin, "Effects of Stretching Exercise Training and Ergonomic Modifications on Musculoskeletal Discomforts of Office Workers: A Randomized Controlled Trial,” Brazilian J. Phys. Ther., vol. 22, no. 2, pp. 144-153, Mar. 2018, DOI: 10.1016/j.bjpt.2017.09.003.

[14] R. S. Valdez, K. M. McGuire, and A. J. Rivera, “Qualitative ergonomics/human factors research in health care: Current state and future directions," Appl. Ergon., vol. 62, pp. 43-71, Jul. 2017, DOI: 10.1016/j.apergo.2017.01.01 6.

[15] T. G. Gates, T. Rich, and R. Blackwood, "Workplace friendships among social work, counseling, and human service educators: Exploring the impact of sexual orientation and friendships in workplace empowerment,” J. Workplace Behav. Health, vol. 34, no. 1, pp. 20-37, Jan. 2019, DOI: 10.1080/15555240.2018.1553622.

[16] S. A. Khan and K. Yee Chew, "Effect of working characteristics and taught ergonomics on the prevalence of musculoskeletal disorders amongst dental students,” BMC Musculoskelet. Disord., vol. 14, 2013, DOI: 10.1186/1471-2474-14-118.

[17] J. H. Kamaroddin, W. F. Abbas, M. A. Aziz, N. M. Sakri, and A. Ariffin, "Investigating ergonomics awareness among university students," in Proceedings - 2010 International Conference on User Science and Engineering, i-USEr 2010, 2010, pp. 296-300, DOI: 10.1109/IUSER.2010.5716769.

[18] M. Z. Bin Mustafa, M. N. Bin Nordin, and A. R. Bin Abdul Razzaq, "Structural Equation Modelling using AMOS: Confirmatory Factor Analysis for Taskload of Special Education Integration Program Teachers,” Univers. J. Educ. Res., vol. 8, no. 1, pp. 127-133, Jan. 2020, DOI: 10.13189/ujer.2020.080115.

[19] S. Deep, B. M. Salleh, and H. Othman, "Improving the soft skills of engineering undergraduates in Malaysia through problem-based approaches and e-learning applications," High. Educ. Ski. Work. Learn., vol. 9, no. 4, pp. 662-676, Jan. 2019, DOI: 10.1108/HESWBL-07-2018-0072.

[20] B. L. Botina A, M. C. García M, and Y. Romero B, "Pre- and Post-harvest Factors that Affect the Quality and Commercialization of the Tahiti Lime," Sci. Hortic. (Amsterdam). vol. 257, Nov. 2019, DOI: 10.1016/j.scienta.2019.108737.

[21] A. Esa, A. Selamat, S. Padil, and J. Jamaludin, “Applications of Soft Skills in Engineering Programme at Polytechnic Malaysia,” Procedia - Soc. Behav. Sci., vol. 140, pp. 115120, Aug. 2014, DOI: 10.1016/j.sbspro.2014.04.395.

[22] S. A. Pascual and S. Naqvi, “An Investigation of Ergonomics Analysis Tools used in Industry in the Identification of Work-related Musculoskeletal Disorders," 
Int. J. Occup. Saf. Ergon., vol. 14, no. 2, pp. 237-245, 2008, DOI: 10.1080/10803548.2008.11076755.

[23] D. Kee and W. Karwowski, “A Comparison of Three Observational Techniques for Assessing Postural Loads in Industry,” Int. J. Occup. Saf. Ergon., vol. 13, no. 1, pp. 3-14, 2007, DOI: 10.1080/10803548.2007.11076704.

[24] G. R. Kumar, S. T. Bezawada, N. Sinno, and M. Ammoun, “The impact of ergonomics on employees' productivity in the architectural workplaces,” Int. J. Eng. Adv. Technol., vol. 8, no. 5, pp. 1122-1132, May 2019, DOI: 10.35940/ijeat.E1157.0585C19.
[25] J. Seo, S. Lee, T. Armstrong, and S. Han, "Dynamic biomechanical simulation for identifying risk factors for work-related musculoskeletal disorders during a construction task," in ISARC 2013 - 30th International Symposium on Automation and Robotics in Construction and Mining, Held in Conjunction with the 23rd World Mining Congress (2013), 2013, pp. 1074-1084.

[26] M. S. Rozlina, M. S. Awaluddin, S. H. S. Abdul Hamid, and Z. Norhayati, "Perceptions of ergonomics importance at workplace and safety culture amongst safety \& health (SH) practitioners in Malaysia,” Lect. Notes Eng. Comput. Sci., vol. 2197, pp. 372-376, 2012. 